\title{
COMPARISON OF SEISMIC BEHAVIOR OF CONVENTIONAL SLAB, FLAT SLAB AND GRID SLAB USING RESPONSE SPECTRUM METHOD FOR AN UNSYMMETRIC PLAN
}

\author{
Sharan P \\ P.G. student \\ Department of Civil engineering \\ Malnad College of Engineering, Hassan, \\ Karnataka state, India.
}

\author{
Dr H S Narashimhan \\ Associate professor \\ Department of Civil engineering \\ Malnad College of Engineering, Hassan, \\ Karnataka state, India
}

\begin{abstract}
Conventional slab, flat slab and grid slab is compared its seismic behavior for an unsymmetrical plan using response spectrum method with the help of software ETABS. By taking particular building model with same optimized column size and analyzed for zone II condition. It shows that flat slab showing higher max storey displacement and max storey drift. Conventional slab has higher storey shear. Grid slab showing higher storey stiffness.
\end{abstract}

Keywords - Conventional slab, Flat slab, Grid slab, Response spectrum method, Max storey displacement, Max storey drift, Storey shear, Storey stiffness.

\section{INTRODUCTION}

India is a fastest developing country with large manpower and natural resources. Day by day the growth in every aspects is increasing thereby creating a demand for sufficient infrastructure. Mangalore, Bangalore and Delhi are the fastest growing cities where there is insufficient availability of land space creating the need for high rise buildings. The construction of high rise buildings using reinforced concrete material is very common all over the world. The slab in a R.C building is a most important horizontal structural component in a building. Which accepts loads and transfer to beams, columns, hence to ground. The main objectives of this project is:

1. To find response of different types of slabs subjected to earthquake load.

2. To analyze the behavior of different type of slab in different earthquake zones.

\section{DIFFERENT TYPE OF SLAB}

A. Conventional slab system

B. Flat slab system

\section{Grid slab system}

\section{A. Conventional slab system -}

Conventional slab is traditional method used in the construction of residential buildings and small construction. Here all the 4 edges of the slabs are supported by beams by which the loads are transferred to columns. The design for the larger span or maximum load can be done by increasing the depth of the beams and cross section of the columns without any significant increase in the depth of slab.

\section{B. Flat slab system -}

A flat slab is a one-way or two-way system with thickenings in the slab at the columns and load bearing walls called 'drop panels'. It is also called as beamless slab, because slab supported directly by column without beams. Drop panels act as T-beams over the supports. They increase the shear capacity and the stiffness of the floor system under vertical loads, thus increasing the economical span range. The flat slab is often thickened closed to supporting columns to provide adequate strength in shear and to reduce the amount of negative reinforcement in the support region.

\section{Grid slab system -}

Grid floor systems consisting of beams spaced at regular intervals in perpendicular directions, monolithic with slab. They are generally employed for architectural reasons for large rooms such as auditoriums, theatre halls, show rooms of shops where column free space is often the main requirement. The rectangular or square void formed in the ceiling is advantageously utilized for concealed architectural lighting. The sizes of the beams running in perpendicular directions are generally kept the same. 


\section{International Journal of Engineering Applied Sciences and Technology, 2019 Vol. 4, Issue 2, ISSN No. 2455-2143, Pages 141-145 \\ Published Online June 2019 in IJEAST (http://www.ijeast.com)}

\section{EARTHQUAKE}

An earthquake may be defined as a shaking of earth's surface from the earth crust that releases seismic waves. Earthquakes can be violent enough to toss people around and destroy whole area. Earthquakes are caused mostly by rupture of geological faults, but also by other events such as volcanic activity, landslides, mine blasts and nuclear test.

A. Effects of earthquakes on buildings -
1. Direct effects
- Ground failures or instabilities due to ground failures
- Vibrations transmitted from the ground to the structure

2. Indirect effects

- Consequential phenomenon

\section{LITERATURE REVIEW}

Sandesh D., Bothara. et.al., (2012) studied the comparative effect of the seismic performance of Flat Slab and Grid Slab system consisting of beams spaced at regular intervals in perpendicular directions, monolithic with slab. In their work, the authors performed the dynamic analysis of a 9-Storey building with flat slab and grid slab using Response Spectrum method and the comparative results are shown in terms of storey drift, shear force and maximum moment. Importance of drops in flat slabs for increasing the shear strength was confirmed. Grid slabs showed lesser drift compared to flat slabs at higher levels. However, up to four stories, the drift was identical.

R.S. More, V.S. Sawant., et.al (2013) Presented the paper in analyzing the study of different types of flat slab subjected to dynamic loading for different zones. A popular form of concrete building construction uses a flat concrete slab (without beams) as the floor system. Here we consider storey drift as per IS specification. The storey drift in any storey due to the minimum specified design lateral force with partial load factor 1.00 shall not exceed 0.004 times the storey height. In this case, storey height is $4200 \mathrm{~mm}$. so they got $16.8 \mathrm{~mm}$. Drift of flat plate is maximum than grid floor slab and flat slab. Grid slab has less drift compared to others. Drift or relative displacement of a storey is the ratio of base shear experienced by that storey to total stiffness of columns at that storey. Since stiffness of columns for a given storey is same for all three types of slabs, maximum drift indicates maximum base shear for flat plate slab. Flat plate experiences maximum shear force, whereas grid slab experiences less shear force.

Salman I Khan, et.al., (2014) Studied the comparative seismic performance of flat slab buildings and grid slab buildings. Dynamic analysis of three different high rise buildings having $12,15 \& 18$ stories is performed using response spectrum method for all four seismic zones of India, as categorized by the Indian code for earthquake resistant structures. The assessment of the seismic response is based on the maximum inter-story drift, roof displacement, Time period and base shear. It is observed that the seismic performance of grid slab buildings was better as compared to that of flat slab buildings.

Navyashree, et.al., (2014) compared the behavior of multistorey commercial buildings having flat slabs and conventional RC frame. This work provides a good source of information on the parameters like lateral displacement, storey drift, storey shear, column moments and axial forces, time period, etc. The authors broadly concluded that, the lateral displacement was maximum at terrace level for all types of columns. Lateral displacement increased as the storey level increased. Lateral displacement of conventional RCC building was less than the flat slab building. The natural time period increased as the height increased (No. of stories). The time period was more for flat slab building than conventional building. The storey drift in building with flat slab construction was significantly more as compared to conventional RCC building. As a result of this, additional moments were developed. Therefore, the columns of such buildings should be designed by considering additional moments caused by the drift.

\section{SCOPE}

1. The lateral behavior of building which is designed according to I.S.1893 is evaluated by means of dynamic method.

2. This gives a clear picture to a civil engineer (structural design engineer) to adopt the appropriate slab system for the structure in the respective earthquake zone.

\section{EARTHQUAKE ANALYSIS OF BUILDINGS}

\section{A. Methods of Earthquake Analysis}

The seismic analysis of buildings can be carried out in two methods

1) Equivalent static method

2) Dynamic Analysis

i) Response spectrum method

ii) Time history method

\section{B. Response spectrum method}

The seismic forces strikes the foundation of a structure will move with the ground motion. It shows that structure 
Published Online June 2019 in IJEAST (http://www.ijeast.com)

movement is generally more than the ground motion. The movement of the structure as compared to the ground is refused as the dynamic amplification. It depends on the natural frequency of vibration, damping, type of foundation, method of detailing of the structure. The response "design acceleration spectrum" which refers to the max acceleration called spectral acceleration coefficient $\mathrm{Sa} / \mathrm{g}$, as a function of the structure for a specified damping ratio for earthquake excitation at the base for a single degree freedom system.

C. Present Investigation

Table -1: Preliminary Data

\begin{tabular}{|c|c|c|}
\hline Sl.No & Properties & Preliminary Data's \\
\hline 1 & No of storey & $\mathrm{G}+10$ \\
\hline 2 & $\begin{array}{l}\text { Floor to floor } \\
\text { height }\end{array}$ & $3.2 \mathrm{~m}$ \\
\hline 3 & Size of beam & $300 \times 650 \mathrm{~mm}$ (Floor beams) \\
\hline 4 & Size of column & $\begin{array}{l}800 \times 800 \mathrm{~mm}\left(\text { Base }-4^{\text {th }} \text { floor }\right) \\
650 \times 650 \mathrm{~mm}\left(4^{\text {th }} \text { floor }-7^{\text {th }}\right. \\
\text { floor }) \\
500 \times 500 \mathrm{~m}\left(7^{\text {th }} \text { floor }- \text { Terrace }\right. \\
\text { Floor })\end{array}$ \\
\hline 5 & Wall thickness & $200 \mathrm{~mm}$ \\
\hline 6 & $\begin{array}{l}\text { Grade of } \\
\text { concrete }\end{array}$ & M25 \\
\hline 7 & Grade of steel & Fe500 \\
\hline 8 & Zone & II \\
\hline
\end{tabular}

Table 2: Load Calculation [6] [7]

\begin{tabular}{|c|c|c|}
\hline \multicolumn{3}{|c|}{ Table 2: Load Calculation [6] [7] } \\
\hline Sl.No & Types & Load \\
\hline 1 & Live load (Floor) & $3 \mathrm{kN} / \mathrm{m}^{2}$ \\
\hline 2 & Floor finish & $1.5 \mathrm{kN} / \mathrm{m}^{2}$ \\
\hline 3 & Wall load & $11 \mathrm{kN} / \mathrm{m}$ \\
\hline 4 & $\begin{array}{l}\text { Live load } \\
\text { (Terrace) }\end{array}$ & $1.5 \mathrm{kN} / \mathrm{m}^{2}$ \\
\hline
\end{tabular}

Table 4: Load combination [8]

\begin{tabular}{|c|c|}
\hline S1.No & Load Combinations \\
\hline 1 & $1.5(\mathrm{DL}+\mathrm{IL})$ \\
\hline 2 & $1.2(\mathrm{DL}+\mathrm{IL} \pm \mathrm{EL})$ \\
\hline 3 & $1.5(\mathrm{DL} \pm \mathrm{EL})$ \\
\hline 4 & $0.9 \mathrm{DL} \pm 1.5 \mathrm{EL}$ \\
\hline
\end{tabular}

Table 3: Earthquake Data [5]

\begin{tabular}{|c|c|c|c|c|}
\hline $\begin{array}{c}\text { Earthquake } \\
\text { Zone }\end{array}$ & 2 & 3 & 4 & 5 \\
\hline $\begin{array}{c}\text { Zone Factor } \\
(\mathrm{Z})\end{array}$ & 0.1 & 0.16 & 0.24 & 0.36 \\
\hline Importance & 1 & 1 & 1 & \\
\hline
\end{tabular}

\begin{tabular}{|c|c|c|c|c|}
\hline Factor (I) & & & & 1 \\
\hline Soil Type & $\begin{array}{l}\text { Medium } \\
\text { (II) }\end{array}$ & $\begin{array}{l}\text { Medium } \\
\text { (II) }\end{array}$ & $\begin{array}{l}\text { Medium } \\
\text { (II) }\end{array}$ & $\begin{array}{l}\text { Medium } \\
\text { (II) }\end{array}$ \\
\hline $\begin{array}{c}\text { Response } \\
\text { reduction } \\
\text { Factor }(\mathrm{R})\end{array}$ & 3 & 3 & 3 & 3 \\
\hline $\begin{array}{l}\text { Approximate } \\
\text { fundamental } \\
\text { period }(\mathrm{Ta})\end{array}$ & 0.961 & 0.961 & 0.961 & 0.961 \\
\hline
\end{tabular}

VII ETABS MODEL

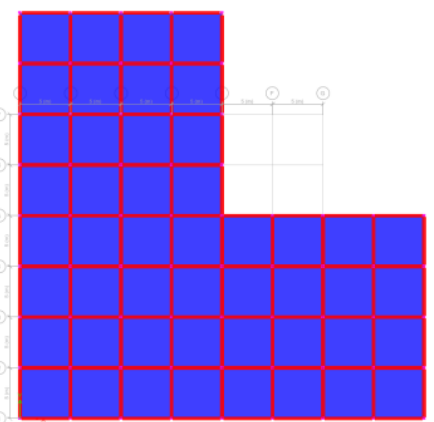

Fig 4: ETABs Plan of Conventional Slab System.

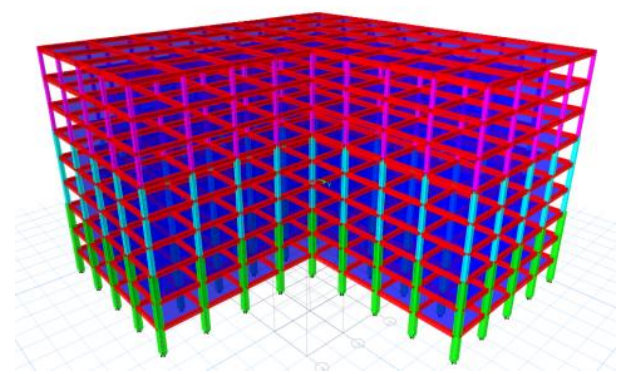

Fig 5: Isometric view of Conventional Slab System.

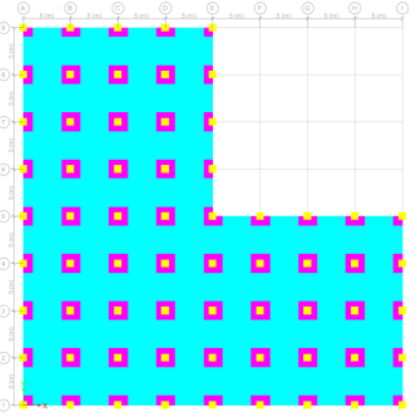

Fig 6: ETABs Plan of Flat Slab system. 


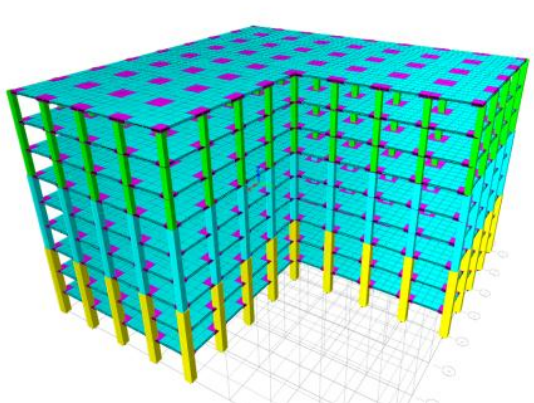

Fig 7: Isometric view of Flat Slab System.

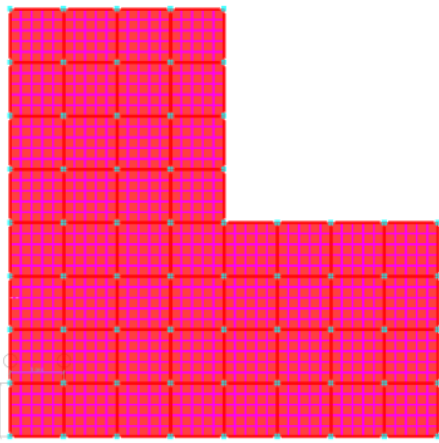

Fig 8: ETABs Plan of Grid System.

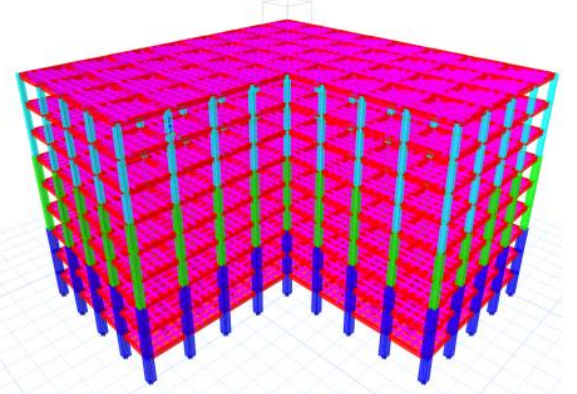

Fig 9: Isometric view of Grid System.

\section{ANALYSIS RESULT}

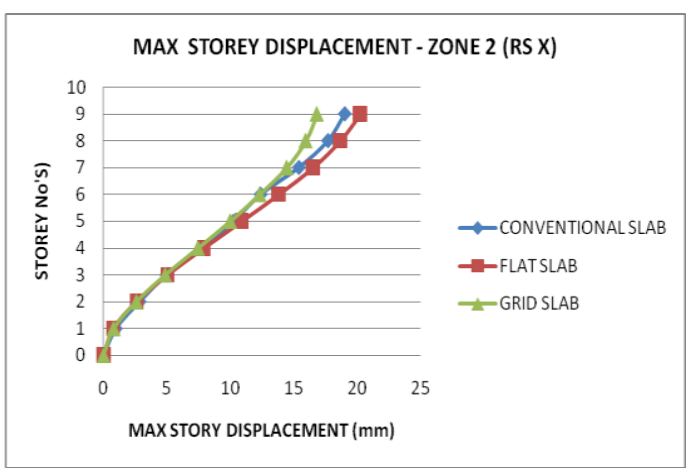

Chart -1: Max Storey Displacement - Zone 2 (RS X).

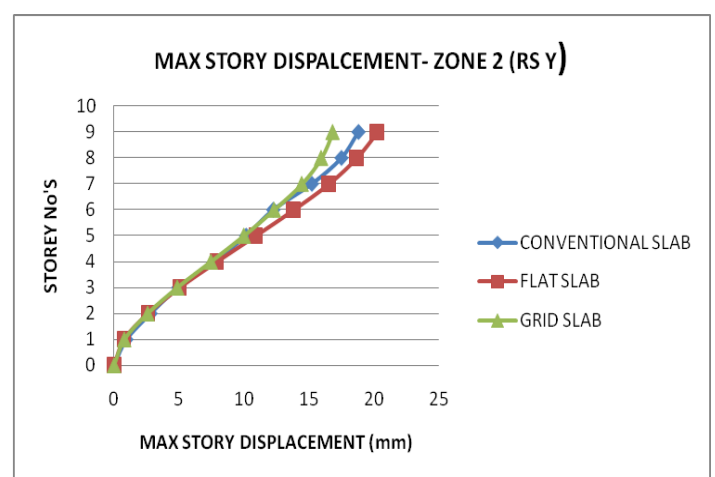

Chart -2: Max Storey Displacement - Zone 2 (RS Y)

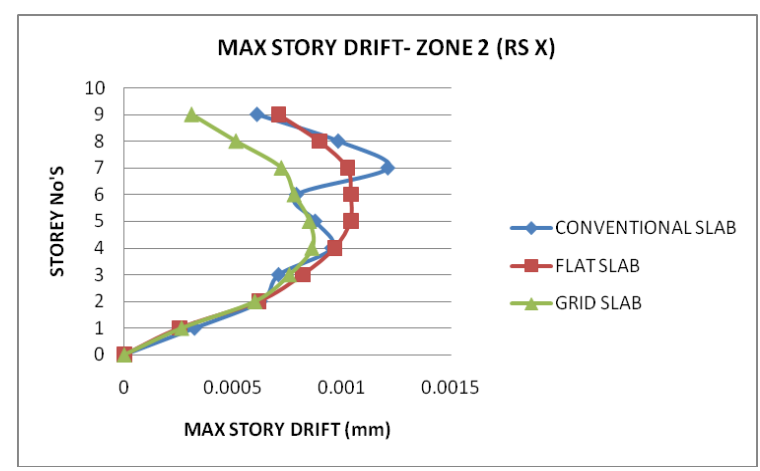

Chart -3: Max Storey Drift - Zone 2 (RS X).

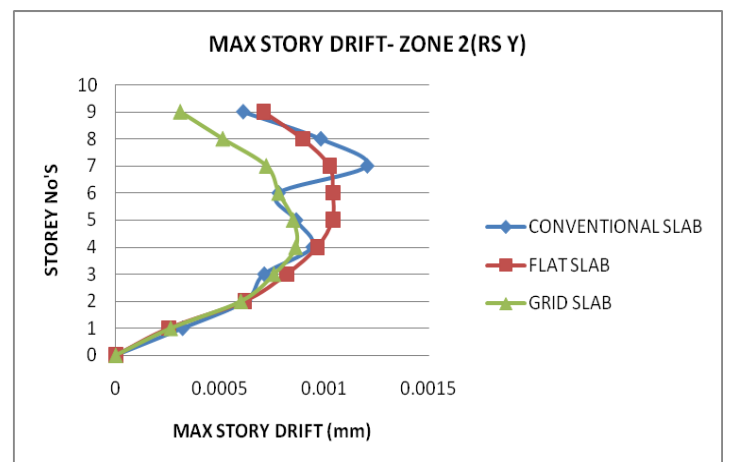

Chart -4: Max Storey Drift - Zone 2 (RS Y).

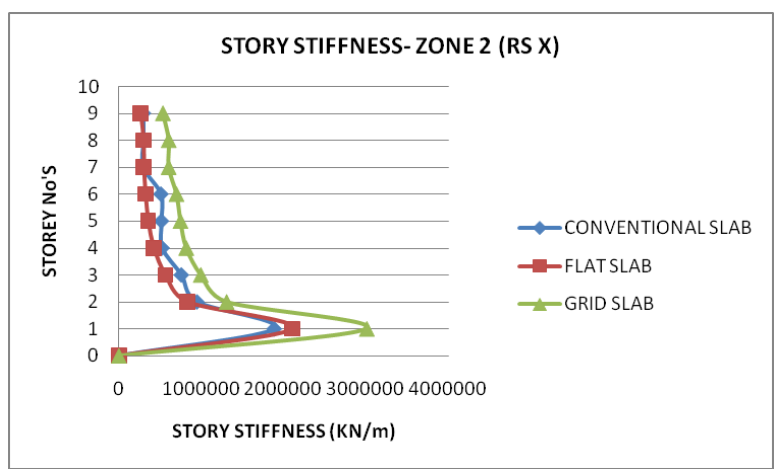

Chart -5: Storey Stiffness - Zone 2 (RS X). 


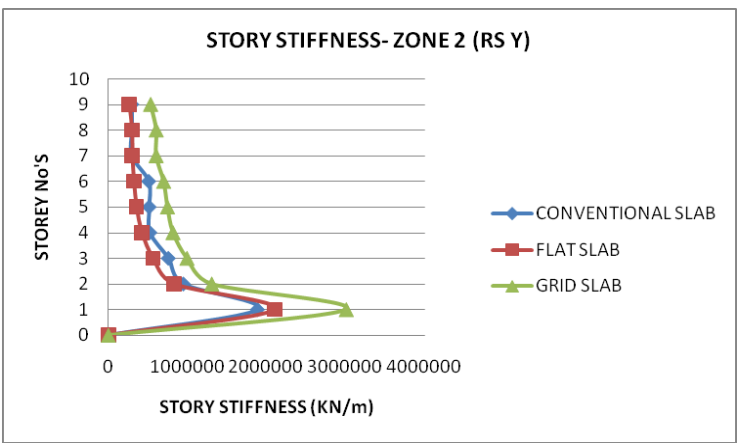

Chart -6: Storey Stiffness - Zone 2 (RS Y).

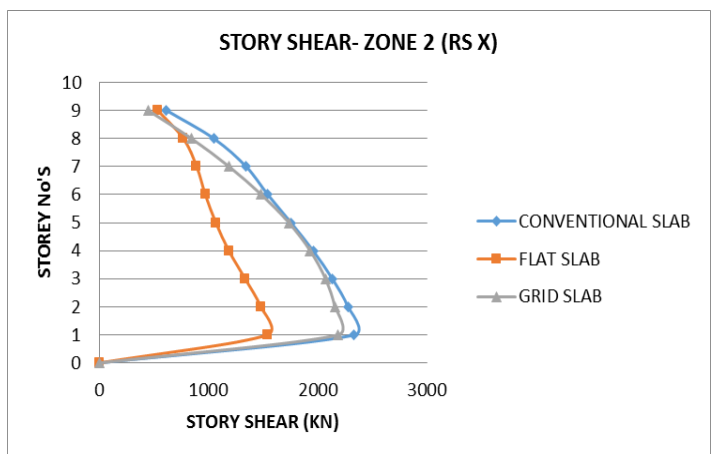

Chart -7: Storey Shear - Zone 2 (RS X).

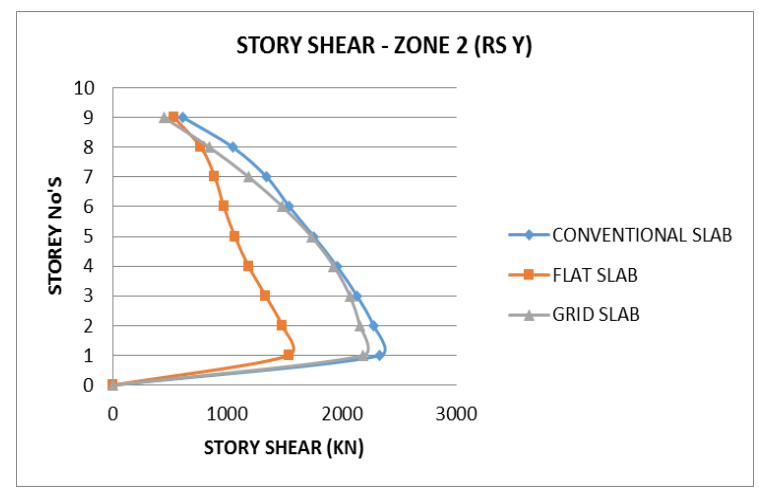

Chart -8: Storey Shear - Zone 2 (RS Y).

\section{RESULT AND DISCUSSION}

A. In Max storey displacement, Max storey drift flat slab is showing higher value due less stiffness of flat slab.

B. In Storey stiffness grid slab is showing higher value due to high stiffness of grid slab.

C. In Storey shear conventional is showing higher value high base shear.

\section{CONCLUSION}

1. In Max storey displacement flat slab is showing higher value i.e. $6.22 \%$ compared to conventional slab and $17.019 \%$ compared to grid slab.
2. In Max storey drift flat slab is showing higher value i.e. $13.84 \%$ compared to conventional slab and $56.21 \%$ compared to grid slab.

3. In Storey stiffness grid slab is showing higher value i.e. $44.46 \%$ compared to conventional slab and $29.88 \%$ compared to flat slab.

4. In Storey shear conventional is showing higher value i.e. $27.35 \%$ compared to grid slab and $13.11 \%$ compared to flat slab.

\section{XI . REFERENCE}

[1] Sandesh D. Bothara, Dr.Valsson Varghese.(July-August 2012) -Dynamic analysis of special moment resisting frame building with flat slab and grid slab , Vol. 2, Issue 4, pp.275-280, ISSN: 2248-9622.

[2] R.S.More, V. S. Sawant, Y. R. Suryawanshi.(2013) Analytical study of different types of flat slab subjected to dynamic loading, IJSR, ISSN (Online): 2319-7064.

[3] Salman I Khan and Ashok R Mundhada.( February 2015) -Comparative study of seismic performance of multistoried rcc buildings with flat slab and grid slab, Vol. 4, No. 1, , ISSN 2319 - 6009.

[4] Navyashree.(September-2014) -Comparative study of flat slab and conventional slab structure using etabs for different earthquake zones of india, Vol.03,Issue.21, Pages:4317-4326, ISSN 2319-8885

[5] IS-1893:2002 (Part-1) Criteria for earthquake resistant design of structure.

[6] IS-875(Part-1)-1987 used for design loads (other than earthquake) for building and structure.

[7] IS-875(Part-2)-1987 used for design loads (other than earthquake) for building and structure.

[8] IS-456: 2000 used for plain and reinforced concrete.

[9] Thummala Spoorthy.- Comparison between the seismic variation of conventional RCSlab and flat slab with a drop for $\mathrm{G}+15$ storey building in Different zones using etabs software, IJARIIT,ISSN: 2454-132X,(Volume 4, Issue 3)

[10] Vishesh P.Thakkar.( April-2017,) - Comparative study of seismic behaviour of flat slab and conventional rc framed structure, IJERT, www.ijert.org, Vol. 6 Issue 04.

[11] Syed Abdul Qavi. (November-2018)- Comparative analysis and design of flat and grid slab systemwith conventional slab system, IJMTE, Volume 8, Issue XI, ISSN NO : 2249-7455.

[12] Dr. M Rame Gowda, Techi Tata.( Sep-2016 )- Study of seismic behavior of building with flat slab, IRJET, Volume: 03, Issue: 09, www.irjet.net

[13] Mr. Tejas B, Mr. Raghu M E(2018) A Study on the Behavior of Grid Slab Subjected to Seismic Loading, IRJET ,Volume: 05 Issue: 08, www.irjet.net p-ISSN: 2395-0072. 